\title{
PERFORMANCE EVALUATION OF A LABORATORY SCALE SPRAY DRYER \\ Bahnasawy, ${ }^{1}$ A. H.; Okasha, ${ }^{2}$ A. E. and E. E. Gonbeej ${ }^{3}$
}

\section{ABSTRACT}

A laboratory scale-spray dryer performance was evaluated experimentally. Powder yield, drying rate, feeding rate, drying time, evaporation rate and energy consumption were investigated under different inlet air temperatures and atomization speeds for drying some milk-juice blends and whole milk. Theoretical approach of the dryer was developed, and energy inputs and outputs were estimated at the same experimental conditions.

The results showed that the powder yield decreased with increasing both inlet air temperature and atomization speed, on the other hand, drying rate and time, feeding rate, evaporation rate increased with increasing both air temperature and atomization speed. Energy consumption decreased with increasing both air temperature and atomization speed, where, it ranged from 36.47 to $53.29 \mathrm{GJ} / \mathrm{kg}$ for the milk-juice blends depending on both atomization speed and drying temperature, while it ranged from 38.53 to $45.70 \mathrm{GJ} / \mathrm{kg}$ for the whole milk. Dryer efficiency increased with increasing drying temperature and atomization speed. It ranged from 42.09 to $71.03 \%$ depending on drying temperature and atomization speed.

Theoretical approach showed that the estimated energy consumption was lower than the actual energy consumed, also, the estimated energy inputs were higher by 4.28 to $5.59 \%$ than the outputs of energy.

Keywords: Spray dryer, performance, energy consumption, dryer efficiency, milk-juice blends, temperature, atomization, powder.

\footnotetext{
${ }^{1}$ Associate Professor of Agric. Eng. Moshtohor, Benha University, (bahnasawyadel@hotmail.com)

${ }^{2}$ Professor of Food Science and Technology, Fac. of Eng. and Technol. Sci., Sebha University, Libya.

${ }^{3}$ Graduate student of Food Science and Technology, Fac. of Eng. and Technol. Sci., Sebha University, Libya
} 


\section{INTRODUCTION}

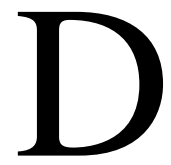

rying is an energy intensive operation. World wide approximately $12 \%$ of the total energy consumption in industrial sectors is being used for drying. Rise in fuel prices is likely to trigger an increase in energy costs and hence eat into the profit margins of the drying industry. To compete in the global market Drying Industries need to reduce energy cost and keep the drying costs low. In conventional hot air based dryers, those which have partial recirculation of air lose a significant amount of heat in the exhaust stream. This is because of low moisture pickup per $\mathrm{kg}$ of air circulated. The heat loss is very high especially when temperature sensitive products are dried using low temperature air. Attention is focused on an industry using conventional hot air based dryer for drying of paper trays. The fuel used is rice husk, with calorific value of $13,800 \mathrm{~kJ} / \mathrm{kg}$. The total amount of fuel fired is $350 \mathrm{~kg} / \mathrm{h}$ to remove $720 \mathrm{~kg} / \mathrm{h}$ of moisture from the paper trays. Air is being heated using fluidized bed rice husk fired air heater. The moisture removal from the paper trays is $0.66 \mathrm{~kg}$ of water $/ \mathrm{kWh}$ of heat considering the efficiency of $80 \%$ for rice husk fired air heater (Rane, et al., 2006).

Spray drying is a very effective and economical technique of powder manufacturing. An attractive feature of spray drying is that the heat damage to the product is small. The development of spray-drying technology has therefore been intimately associated with dairy, food, biotechnology and pharmaceutical industries where heat-sensitive materials have to be dried while maintaining the prerequisite microbiological stability in the dried particles. There have been many theoretical and experimental studies published since the 1950s to study spray-drying operations. Recent studies show that the computational fluid dynamics (CFD) approach is becoming very useful in optimizing and designing the process and equipment (Huang et al., 2003a, b, 2004a). There is a continuous progress in the experimental and the theoretical studies on the spray drying process, Birchal et al. (2006) developed a computer model and simulation for spray dryer, Kota and Langrish (2007a) assessed the deposition of a water spray on a plate in a simple box configuration using computational fluid dynamics. Kota and 
Langrish, (2007b) (prediction of deposition patterns in a pilot-scale spray dryer using computational fluid dynamics (CFD) simulations), Hanus and Langrish (2007) studied the re-entrainment of wall deposits from a laboratory-scale spray dryer.

Rao and Kumer (2005) investigated the effect of various processing parameter on the spray drying of blends with different levels of mango juice and buttermilk, 5:95, 10:90, 15:85 and 20:80 at feed temperature of $40-55{ }^{\circ} \mathrm{C}$ and compressed air pressure of $68-170 \mathrm{kPa}$. They observed that the various processing parameters such as outlet air temperature, total solids and blend proportions had a profound effect on the characteristics of the resultant powder.

Bimbent et al. (2002) studied the principles and application of heat and mass balance for a multistage spray-dryer. They concluded that the heat balance showed a difference between inputs and outputs of $2.9 \%$ which may be interpreted as heat losses and probable errors. The specific heat consumption was close to $4900 \mathrm{~kJ} / \mathrm{kg}$ of evaporated water. This overall value includes the rather low energetic efficiency of the small flow rates of air used in both fluid beds. This specific heat consumption corresponds to 2.1 times the latent heat of vaporization of water at $70{ }^{\circ} \mathrm{C}$, i.e. a thermal efficiency of $48.8 \%$.

Baker and McKenzie. (2002) made a survey, which included dryers having evaporation rates ranging from $0.1-12 \mathrm{t} / \mathrm{h}$. Values of the specific energy consumption (Es) varied widely, ranging from less than 3 to around $20 \mathrm{GJ} / \mathrm{t}$ of evaporated water; the average for all dryers included in the survey was $4.87 \mathrm{GJ} / \mathrm{t}$. As might be anticipated there was a wide scatter in the results. A preliminary analysis of the data indicated that Es showed a small but significant decrease with evaporation rate over most of the range. A small number of dryers operating at very low throughputs $(<1 \mathrm{t} / \mathrm{h}$ evaporation rates) exhibited very high values of Es, often as much as 4-5 times the norm.

Goula and Adamopoulos (2003) investigated the performance of a spray dryer for tomato powder preparation by spray drying of tomato pulp. Data for the residue remaining in the chamber and cyclone walls was gathered and two types of efficiencies were calculated as an indication of the spray dryer performance. Analysis of experimental data 
yielded correlations between residue accumulation and the variable operating conditions. The same operating parameters had a great influence on the air outlet temperature whereas temperature deviations were observed comparing measured air outlet temperatures with corresponding outlet adiabatic saturation temperatures.

From the pervious work, it seems that the drying conditions have a very significant impact on the dryer performance, so this work has mainly focused on investigating the possibility of drying some milk-juice blends and studying the effect of the some operational conditions of spray drying such as inlet temperature and atomization speed on the drier performance.

\section{Materials:}

\section{MATERIALS AND METHODS}

\section{Raw materials to be spray dried:}

Cow's milk was obtained from local farms (Sebha, Libya) which contains $11 \%$ total solids. Banana and pear juices were brought from the HH Company, Malta. Strawberry juice made by the El-Behera Lanchor company, UAE.

\section{Description of Spray drier:}

A laboratory spray drier size 1 (Anhydro A/S, Ostmarken 8, DK-2860 Soborg, Copenhagen, Denmark) was used in this study as shown in Fig. 1 , ( $\mathrm{a}$ and $\mathrm{b}$ ). The spray dryer has an internal diameter of $1.0 \mathrm{~m}$ and a height of $2.6 \mathrm{~m}$. The upper cylindrical portion of the unit is $1.3 \mathrm{~m}$ in height, and the lower conical section has a height of $1.3 \mathrm{~m}$. The maximum inlet and outlet temperatures are 300 and $90{ }^{\circ} \mathrm{C}$, respectively. Maximum atomizer speed is $50000 \mathrm{rpm}$ which is obtained by $0.74 \mathrm{~kW}$ electric motor. Air is heated using a maximum power of $9 \mathrm{~kW}$ and forced with a flow rate of $120 \mathrm{~L} / \mathrm{min}$ at maximum pressure of 4 bars.

\section{Operating parameters:}

The inlet temperature and the atomization speed were the most important factors affecting the drier performance. Three temperatures were used to spray the mixed juice-milk liquid, including 190, 220, and $250{ }^{\circ} \mathrm{C}$ and three atomization speeds were 18000, 22000, and $26000 \mathrm{rpm}$. 


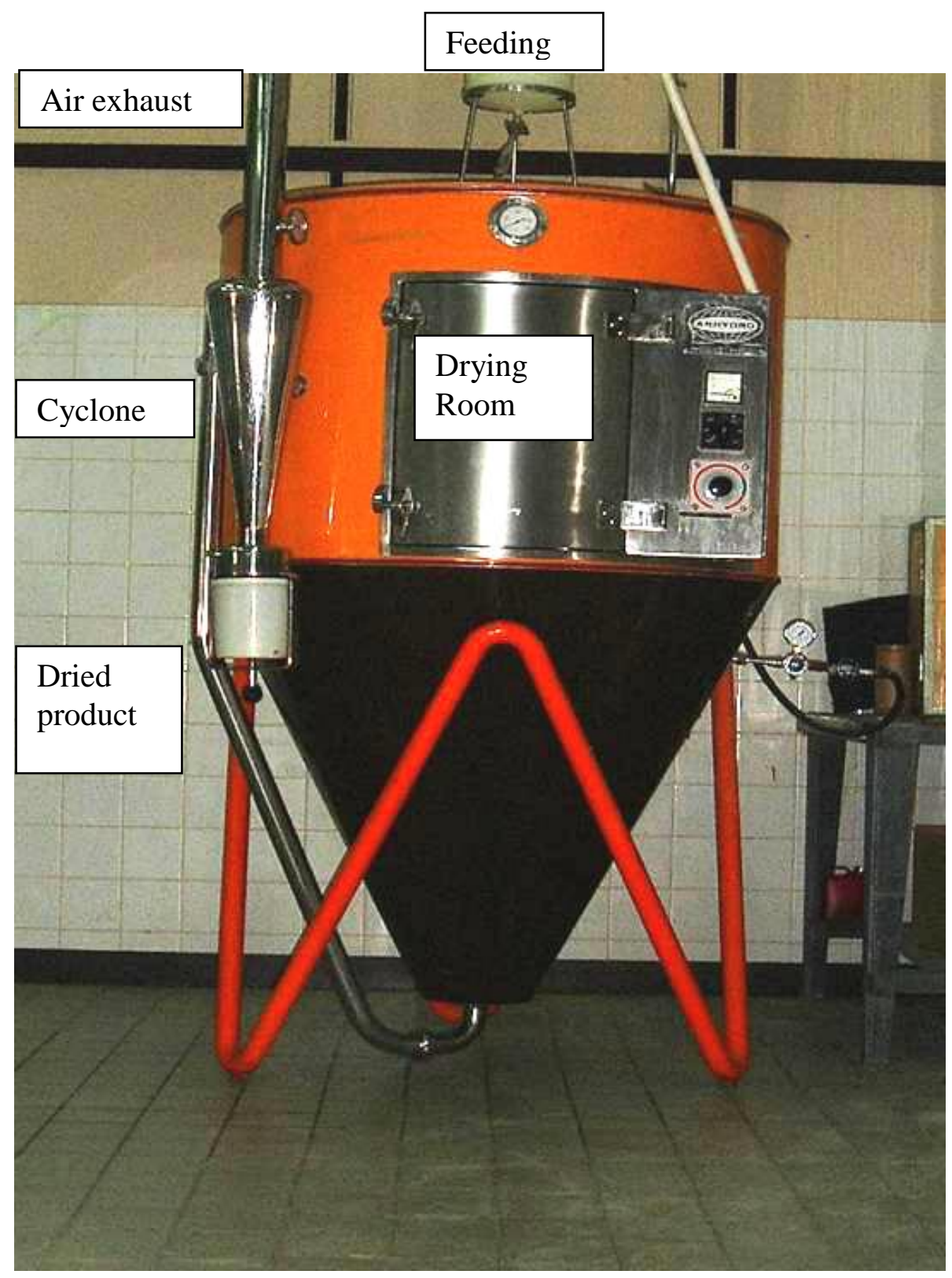

Figure 1a: Photograph of the lab-scale spray dryer. 


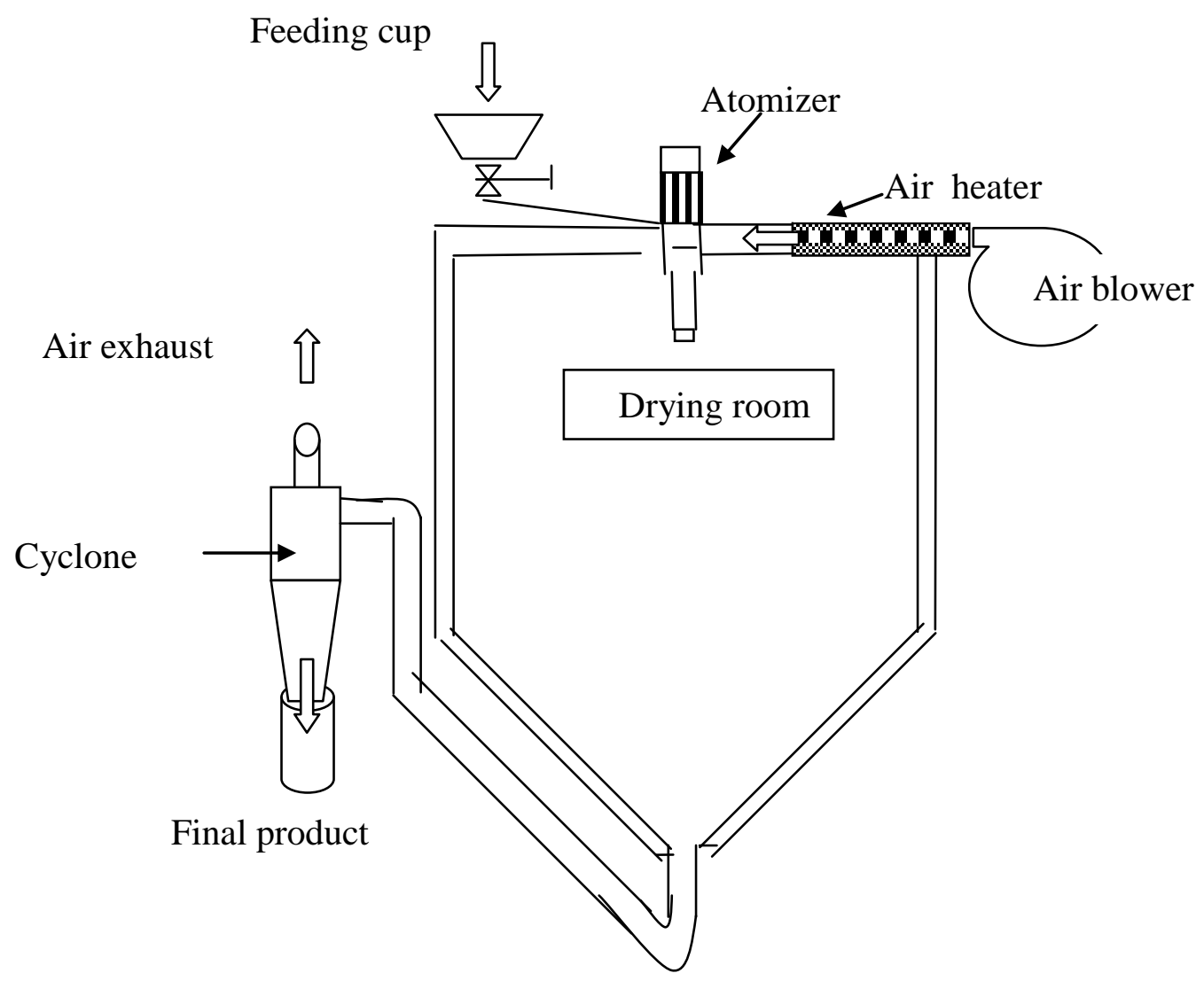

Figure 1b. Schematic diagram of the lab-scale spray dryer.

\section{Methods:}

Milk was screened and heated up to $70^{\circ} \mathrm{C}$ for $15 \mathrm{~min}$ and then mixed with the juices at a rate of 1:2 (milk: juice). Three blends namely, milkbanana, milk-strawberry and milk-pear were obtained in addition to the whole milk. These blends were homogenized and screened again using cheese cloth and then total solids concentrations were measured using the refractmeter (Model ATAGO N1, Brix 0 32\%, Japan) before drying which was found to be an average of $13 \%$. The dryer has to be cleaned before each run of drying. Drier was locked and switched on to reach the desired drying temperatures (190, 220 and $\left.250^{\circ} \mathrm{C}\right)$. The atomizer was adjusted at the desired rotation speed (18000, 22000 , and $26000 \mathrm{rpm}$ ), and then the feeding cup was filled with distilled water and water was sprayed to be certain the nozzles were operating cleanly. After evaporation of water, blends are to be fed to the drier with 
monitoring the outlet temperature, which should not exceed $85^{\circ} \mathrm{C}$, in case of increasing the outlet temperature; feeding rate is responsible in controlling the outlet temperature to the desired degree. By the end of drying process, the drier was left for a few minutes to cool down, opened, and powder is collected and weighed. Drying time and feeding rate were recorded. The drier will be cleaned again for next operation. A total of 36 runs $(3 \times 3 \times 4)$ were carried out in this work, and all runs were repeated three times.

\section{Spray drier performance parameters:}

Powder yield, drying time, drying rate, and feeding rate were recorded at different inlet temperatures and atomization speeds for the materials to be dried (milk-juice blends and whole milk). Water evaporation rate, total energy consumption and drying efficiency were estimated at the same pervious conditions and for the same materials. Evaporation rate was determined using the following equation:

Evaporation rate $(\mathrm{kg} / \mathrm{h})=$

$$
\underline{\text { Feeding rate }(\mathrm{kg} / \mathrm{h}) \times(\text { Ts in powder }- \text { Ts in liquid, \%) }}
$$

$$
\text { Ts in powder, } \%
$$

\section{Energy consumption:}

The total energy consumed in spray drying includes: (a) Energy required for atomization, (b) Energy required for forcing the heated air, and (c) Energy required for heating the air.

Energy required for atomization was estimated as the atomizer power was $0.74 \mathrm{~kW}$ as the atomizer working at maximum speed of $50000 \mathrm{rpm}$. Energy required for forcing air was calculated form the power of blower working on 4 bar pressure and at flow rate of $120 \mathrm{~L} / \mathrm{min}$. Concerning, energy required for heating, it was calculated according the inlet air temperature $\left(190,220\right.$, and $\left.250{ }^{\circ} \mathrm{C}\right)$, where, heating system was adjusted on 5,6 , and $7 \mathrm{~kW}$ to obtained the predetermined temperatures. The energy required for evaporation of moisture and the energy lost in the exit air stream dominates the energy demand in a dryer. Practically, the 
thermal or energy efficiency $(\eta)$ of a drying technology is defined as (Ramaswamy and Marcotte, 2006):

$$
\eta=\frac{\text { energy for evaporation }}{\text { total energy supplied }}
$$

\section{Theoretical approach:}

\section{Energy inputs:}

The hot air and the liquid cause energy to enter the dryer, and the energy flow rate is the product of the enthalpy of each stream and the mass flow rate of that stream.

For the hot air, the enthalpy is given by the following equation (Langrish, 2009):

$$
\mathrm{E}_{\mathrm{a}}=\mathrm{C}_{\mathrm{Pa}}\left(\mathrm{T}_{\mathrm{a}}-\mathrm{T}_{\mathrm{ref}}\right)+\mathrm{H}_{\mathrm{a}}\left(\mathrm{L}+\left(\mathrm{C}_{\mathrm{Pv}}\left(\mathrm{T}_{\mathrm{a}}-\mathrm{T}_{\mathrm{ref}}\right)\right.\right.
$$

where :

$\mathrm{C}_{\mathrm{Pa}}=$ specific heat capacity of dry air $(1.005 \mathrm{~kJ} / \mathrm{kg} \mathrm{K})$,

$\mathrm{T}_{\mathrm{a}}=$ inlet air temperature, ${ }^{\circ} \mathrm{C}$,

$\mathrm{T}_{\text {ref }}=$ reference temperature, $\left(0{ }^{\circ} \mathrm{C}\right)$,

$\mathrm{H}_{\mathrm{a}}=$ air humidity, $\mathrm{kg}$ water/kg dry air,

$\mathrm{L}$, latent heat of vaporization, $(2500 \mathrm{~kJ} / \mathrm{kg})$,

$\mathrm{C}_{\mathrm{Pv}}=$ specific heat capacity of pure water vapor $(1.9 \mathrm{~kJ} / \mathrm{kg} . \mathrm{K}$, Langrish, 2009.).

The enthalpy of liquid water (same pattern for solids in water) is given by the equation:

$$
\mathrm{E}_{\mathrm{L}}=\mathrm{C}_{\mathrm{PL}}\left(\mathrm{T}_{\mathrm{L}}-\mathrm{T}_{\mathrm{ref}}\right)
$$

Where:

$\mathrm{C}_{\mathrm{PL}}=$ specific heat capacity of liquid water $(4.2 \mathrm{~kJ} / \mathrm{kg} . \mathrm{K})$, $\mathrm{T}_{\mathrm{L}}=$ water temperature, $\mathrm{C}$.

The enthalpy entering with the milk solids $\left(\mathrm{E}_{\mathrm{s}}\right)$ is given by

$$
\mathrm{E}_{\mathrm{s}}=\mathrm{C}_{\mathrm{Ps}}\left(\mathrm{T}_{\mathrm{s}}-\mathrm{T}_{\mathrm{ref}}\right)
$$

Where:

$\mathrm{C}_{\mathrm{Ps}}=$ specific heat capacity of powder solids (kJ/ kg.K),

$\mathrm{T}_{\mathrm{s}}=$ solid temperature, ${ }^{\circ} \mathrm{C}$. 


\section{Energy output}

Energy leaves the dryer mainly through moisture, air, but also with the solids, which contain some moisture. The energy losses from the dryer were neglected. The assumption is made that the outlet solids are close to being in equilibrium with the outlet gas, so it follows from this assumption that the temperature of the gas and the solids is likely to be very similar (the same), and the outlet moisture content of the solids is likely to be equal to the equilibrium moisture content of solids in contact with the outlet gas.

For the air, the enthalpy of the air leaving the dryer $\left(\mathrm{E}_{\text {out }}\right)$ is determined by: $\quad \mathrm{E}_{\text {out }}=\mathrm{C}_{\mathrm{Pa}}\left(\mathrm{T}_{\text {out }}-\mathrm{T}_{\text {ref }}\right)+\mathrm{H}_{\text {out }}\left(\mathrm{L}+\left(\mathrm{C}_{\mathrm{Pv}}\left(\mathrm{T}_{\text {out }}-\mathrm{T}_{\text {ref }}\right)\right.\right.$

$\mathrm{H}_{\text {out }}$ is the humidity ratio of the air leaving the dryer, $\mathrm{kg}$ of water $/ \mathrm{kg}$ of dry air.

In the solids, the enthalpy is given by:

$$
\mathrm{E}_{\mathrm{so}}=\mathrm{C}_{\mathrm{Ps}}\left(\mathrm{T}_{\mathrm{so}}-\mathrm{T}_{\mathrm{ref}}\right)+\mathrm{X}_{\mathrm{o}} \mathrm{C}_{\mathrm{PL}}\left(\mathrm{T}_{\mathrm{so}}-\mathrm{T}_{\mathrm{ref}}\right)
$$

$\mathrm{X}_{\mathrm{o}}$ if the final moisture content of powder, $\% \mathrm{db}$

$\mathrm{T}_{\mathrm{so}}$ is the temperature of the powder leaving the dryer, ${ }^{\circ} \mathrm{C}$.

The characteristics of air incoming and leaving the drier at under study temperatures are shown in table (1)

Table (1) The air characteristics at different inlet temperatures

\begin{tabular}{lccc}
\hline \multicolumn{1}{c}{ Parameters } & \multicolumn{3}{c}{ Air Characteristics } \\
\cline { 2 - 3 } Dry-bulb temperature, ${ }^{\circ} \mathrm{C}$ & 190 & 220 & 250 \\
Humidity ratio, $\mathrm{kg} / \mathrm{kg}$ & 0.01 & 0.01 & 0.01 \\
Relative humidity, \% & 0.088 & 0.0465 & 0.028 \\
Specific volume, $\mathrm{m}^{3} / \mathrm{kg}$ & 1.929 & 2.054 & 2.177 \\
Enthalpy, $\mathrm{kJ} / \mathrm{kg}$ & 221.4 & 253 & 284.4 \\
Wet-bulb temperature, ${ }^{\circ} \mathrm{C}$ & 39.5 & 42.0 & 44.2 \\
\hline & & Outputs & \\
Dry-bulb temperature, ${ }^{\circ} \mathrm{C}$ & 85 & 85 & 85 \\
Humidity ratio, $\mathrm{kg} / \mathrm{kg}$ & 0.051 & 0.063 & 0.075 \\
Relative humidity, $\%$ & 9.31 & 11.3 & 13.2 \\
Specific volume, $\mathrm{m}^{3} / \mathrm{kg}$ & 1.59 & 1.62 & 1.65 \\
Enthalpy, $\mathrm{kJ} / \mathrm{kg}$ & 221.4 & 253 & 284.4 \\
Wet-bulb temperature, ${ }^{\circ} \mathrm{C}$ & 39.5 & 42.0 & 44.2 \\
\hline
\end{tabular}




\section{RESULTS AND DISCUSSIONS}

\section{Dryer performance:}

\section{Powder yield and drying rate:}

The effect of atomization speed $(18000,22000$, and $26000 \mathrm{rpm})$ and drying temperature $\left(190,220\right.$ and $\left.250^{\circ} \mathrm{C}\right)$ of spray drying on the powder yield and drying rate of some milk-juice blends are shown in Table (2). The results showed that the powder yield decreased slightly with increasing both atomization speed and drying temperature for all blends under study. The powder yield decreased from 100.2 to $88.5,95$ to 88.12 and from 94 to $86.14 \mathrm{~g} / \mathrm{L}$ for the milk-banana, milk-strawberry, milk-pear blends, respectively, when the atomization speed increased from 18000 $26000 \mathrm{rpm}$ and drying temperature increased from $190-250^{\circ} \mathrm{C}$. However, the powder yield of the whole milk ranged from 85.30 to $101.20 \mathrm{~g} / \mathrm{L}$ under the same operation conditions. These results may be due to the powder resulted at higher temperatures and speeds is very fine particles which some of them go out with exhaust air.

Regarding the effect of atomization speed and temperature on the drying rate, it could be seen that the drying rate increased with increasing both atomization speed and drying temperature for all blends and whole milk. The results showed that the lowest drying rate $(0.37 \mathrm{~kg} / \mathrm{h})$ was recorded at the lower atomization speed and drying temperature (18000 rpm and $190{ }^{\circ} \mathrm{C}$ ) for milk-banana blends, while the highest drying rate $(0.71 \mathrm{~kg} / \mathrm{h})$ was recorded at the higher atomization speed and drying temperature (26000 rpm and 250 C) for milk-strawberry blends.

\section{Drying time and feeding rate:}

Table (3) shows the effect of atomization speed (18000, 22000, and $26000 \mathrm{rpm})$ and temperature $\left(190,220\right.$ and $\left.250^{\circ} \mathrm{C}\right)$ of spray drying on the drying time and feeding rate of some milk-juice blends and whole milk. It could be seen that the drying time decreased with increasing both atomization speed and drying temperature for all blends and whole milk. The results indicated that the time required for drying one liter of milkbanana blend decreased from 2.71 to $1.66 \mathrm{~h} / \mathrm{kg}$ when the atomization speed increased from 18000-26000 rpm and drying temperature increased from $190-250^{\circ} \mathrm{C}$. Meanwhile, it decreased from 2.64 to 1.41 , 2.57 to 1.38 , and 2.32 to $1.45 \mathrm{~h} / \mathrm{kg}$ for milk-strawberry, milk-pear, and 
whole milk respectively, under the same previous atomization speeds and drying temperatures. It could be noticed that the effect of changing temperature was higher than that of the atomization speed, for example, drying time decreased by $30.13 \%$ when the temperature increased from $190-250^{\circ} \mathrm{C}$ at $18000 \mathrm{rpm}$, while it decreased by $17.12 \%$ when the atomization speed increased from 18000 to $26000 \mathrm{rpm}$ at $190{ }^{\circ} \mathrm{C}$, for milk-banana blends. The same trend was occurred for the other blends and whole milk.

Table (2) Effect of atomization speed and temperature of spray drying on the powder yield and drying rate of some dried milk-juice blends.

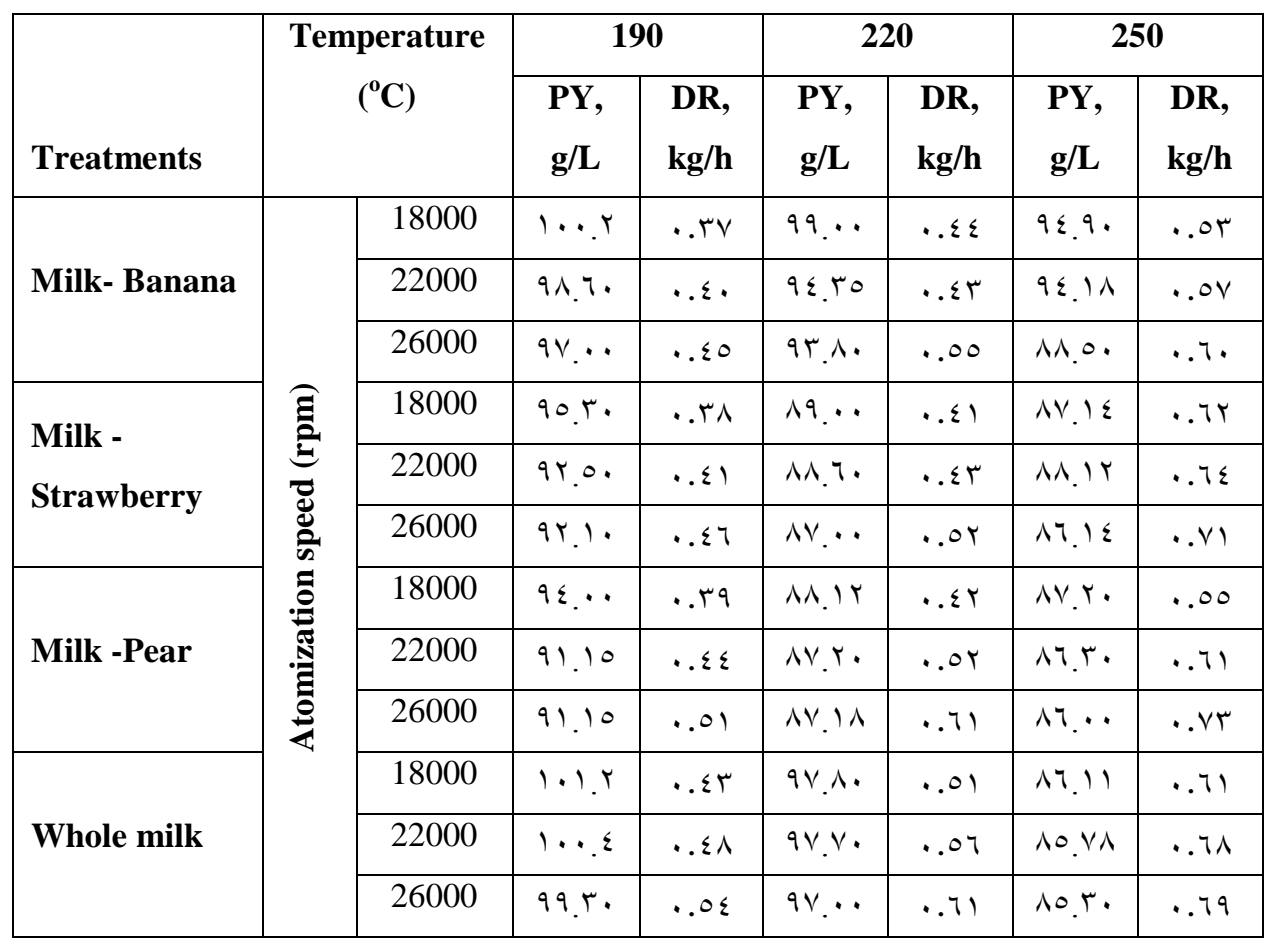

PY is the powder yield

$\mathrm{DR}$ is the drying rate

It is concluded that the drying time decreases with increasing both drying temperature and atomization speed which maybe attributed to with higher atomization speed result in smaller particle sizes with higher surface areas with higher evaporation of moisture especially at higher drying temperatures (Dies, 1997). 
Feeding rate was mainly affected by the outlet temperature, which was maintained at $85{ }^{\circ} \mathrm{C}$. As shown in Table (3), the feeding rate increased with increasing both atomization speed and drying temperature for all blends and whole milk. The results showed that the lowest feeding rate $(3.68 \mathrm{~L} / \mathrm{h})$ was recorded at the lower atomization speed and drying temperature $\left(18000 \mathrm{rpm}\right.$ and $\left.190{ }^{\circ} \mathrm{C}\right)$ for milk-banana blends, while the highest feeding rate $(8.24 \mathrm{~kg} / \mathrm{h})$ was recorded at the higher atomization speed and drying temperature (26000 rpm and $250{ }^{\circ} \mathrm{C}$ ) for milkstrawberry blends.

Table (3) Effect of atomization speed and temperature of spray drying on the drying time and feeding rate of some dried milk-juice blends and whole milk.

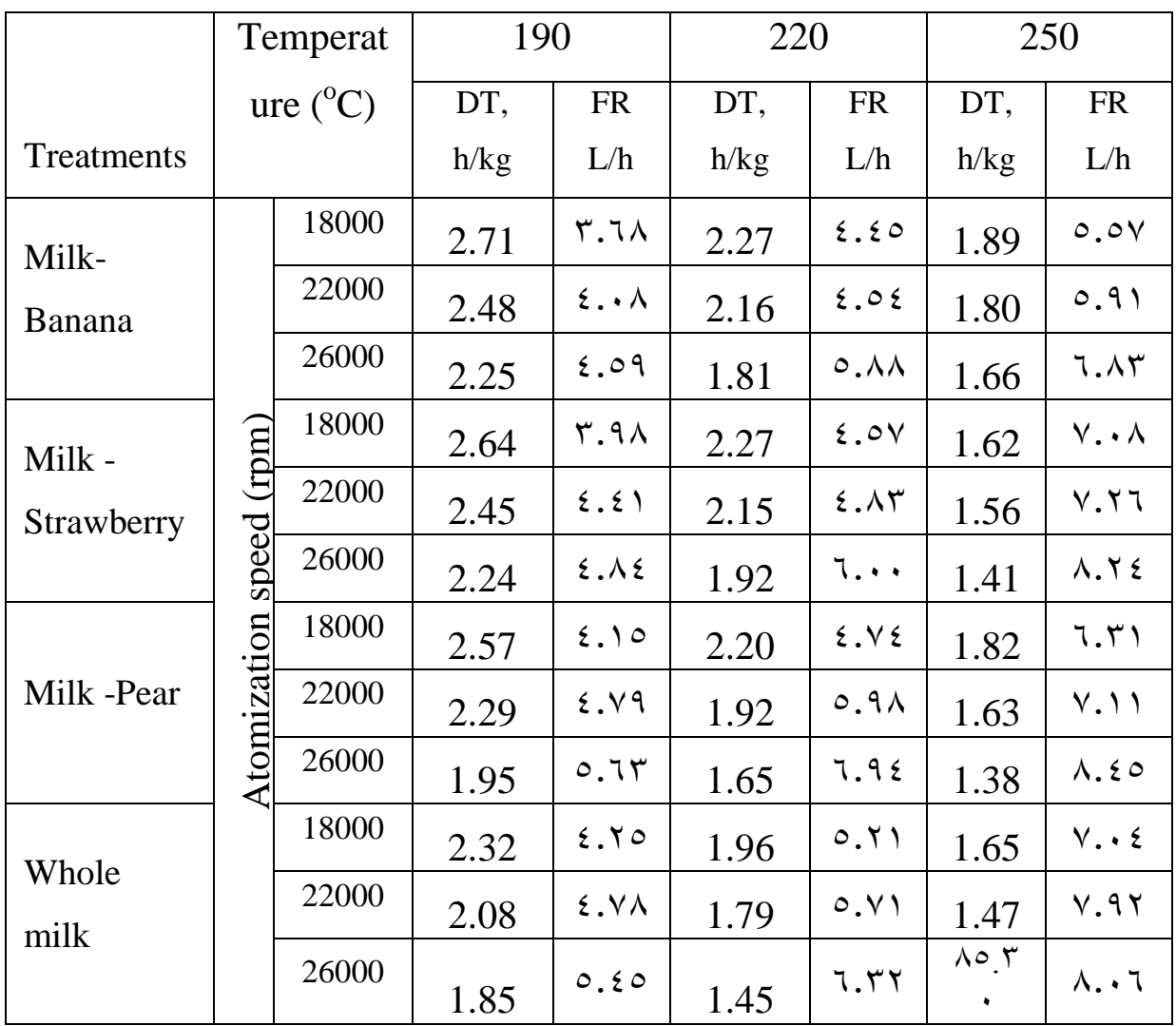

DT, drying time

FR, feeding rate

The results indicated that the effect of changing temperature on the feeding rate was higher than that of the atomization speed, where it 
changed from 3.68 to $5.57 \mathrm{~L} / \mathrm{h}$, with $1.89 \mathrm{~L} / \mathrm{h}$ difference when the temperature changed from 190 to $250{ }^{\circ} \mathrm{C}$, while it changed from 3.68 to $4.59 \mathrm{~L} / \mathrm{h}$, with $0.91 \mathrm{~L} / \mathrm{h}$ difference when the atomization speed changed from 18000 to $26000 \mathrm{rpm}$, for milk-banana blends for example. For whole milk, it changed from 4.25 to $7.11 \mathrm{~L} / \mathrm{h}$, with $2.79 \mathrm{~L} / \mathrm{h}$ difference when the temperature changed from 190 to $250{ }^{\circ} \mathrm{C}$ (at $18000 \mathrm{rpm}$ ), while it changed from 4.25 to $5.45 \mathrm{~L} / \mathrm{h}$, with $0.20 \mathrm{~L} / \mathrm{h}$ difference when the atomization speed changed from 18000 to $26000 \mathrm{rpm}$ (at $190{ }^{\circ} \mathrm{C}$ ).

\section{Moisture content and real evaporation rate:}

The effect of atomization speed $(18000,22000$, and $26000 \mathrm{rpm})$ and temperature $\left(190,220\right.$ and $\left.250^{\circ} \mathrm{C}\right)$ of spray drying on the final moisture content of the powder and real evaporation rate of some milk-juice blends and whole milk is shown in Table (4).

Table (4) Effect of atomization speed and temperature of spray drying on the final moisture content and real evaporation rate of some dried milk-juice blends and whole milk.

\begin{tabular}{|c|c|c|c|c|c|c|c|c|}
\hline \multirow{2}{*}{ Treatments } & \multirow{2}{*}{\multicolumn{2}{|c|}{$\begin{array}{l}\text { Tempera } \\
\text { ture }\left({ }^{\circ} \mathrm{C}\right)\end{array}$}} & \multicolumn{2}{|c|}{190} & \multicolumn{2}{|c|}{220} & \multicolumn{2}{|c|}{250} \\
\hline & & & $\mathrm{MC}$ & RER, & $\mathrm{MC}$ & RER, & $\mathrm{MC}$ & RER, \\
\hline \multirow{3}{*}{$\begin{array}{l}\text { Milk- } \\
\text { Banana }\end{array}$} & & 18000 & 3.60 & 3.31 & 3.40 & 4.01 & 2.90 & 5.04 \\
\hline & & 22000 & 3.29 & 3.68 & 3.08 & 4.08 & 2.45 & 5.35 \\
\hline & & 26000 & 3.08 & 4.15 & 2.17 & 5.33 & 2.10 & 6.23 \\
\hline \multirow{3}{*}{$\begin{array}{l}\text { Milk - } \\
\text { Strawberry }\end{array}$} & & 18000 & 3.99 & 3.60 & 3.70 & 4.13 & 3.50 & 6.46 \\
\hline & & 22000 & 3.87 & 4.00 & 3.53 & 4.37 & 3.00 & 6.62 \\
\hline & & 26000 & 3.84 & 4.39 & 3.20 & 5.48 & 2.72 & 7.53 \\
\hline \multirow{3}{*}{ Milk -Pear } & & 18000 & 3.80 & 3.76 & 3.53 & 4.29 & 3.17 & 5.76 \\
\hline &.$\stackrel{乛}{N}$ & 22000 & 3.52 & 4.35 & 3.37 & 5.46 & 2.76 & 6.50 \\
\hline & 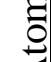 & 26000 & 3.25 & 5.12 & 2.15 & 6.34 & 2.00 & 7.72 \\
\hline \multirow{3}{*}{$\begin{array}{l}\text { Whole } \\
\text { milk }\end{array}$} & & 18000 & 2.57 & 3.82 & 2.15 & 4.70 & 1.93 & 6.43 \\
\hline & & 22000 & 2.30 & 4.30 & 2.03 & 5.15 & 1.91 & 7.24 \\
\hline & & 26000 & 2.01 & 4.91 & 1.95 & 5.69 & 1.80 & 7.37 \\
\hline
\end{tabular}

MC refers to moisture content of powder RER refers to real evaporation rate 
It could be seen that the moisture content decreased with increasing both atomization speed and drying temperature for all blends and whole milk. The results showed that the highest moisture content (3.99\%) was recorded at the lower atomization speed and drying temperature (18000 rpm and $190{ }^{\circ} \mathrm{C}$ ) for the milk-strawberry blends, while the lowest moisture content $(1.8 \%)$ was recorded at the higher atomization speed and drying temperature $\left(26000 \mathrm{rpm}\right.$ and $\left.250{ }^{\circ} \mathrm{C}\right)$ for the whole milk. On the other hands, the moisture content of the milk-juice blends ranged from 2.0 to $3.9 \%$ depending on drying temperature, atomization speed and juice type.

Concerning the real evaporation rate (RER), it could be seen that the evaporation rate increased with increasing both atomization speed and drying temperature for all blends and whole milk. The results showed evaporation rate ranged from 3.31 to $6.23,3.6$ to 7.53 , and 3.76 to 7.72 $\mathrm{kg} / \mathrm{h}$ for milk-banana, milk-strawberry, and milk-pear blends, respectively, whereas, it ranged from 3.82 to $7.37 \mathrm{~kg} / \mathrm{h}$ for whole milk. The results indicate that the real evaporation rate increases with increasing both drying temperature and atomization speed, which is attributed to that high atomization speed results in very small particles with high surface area besides the capability of the air with high temperatures to carry more moisture. The table showed that as the final moisture decreases and the real evaporation rate increases with increasing both drying temperature and atomization speed.

\section{Energy for evaporation $\left(E_{\text {ev }}\right)$ and specific energy consumption (SEC):}

The effect of atomization speed $(18000,22000$, and $26000 \mathrm{rpm})$ and temperature $\left(190,220\right.$ and $\left.250^{\circ} \mathrm{C}\right)$ of spray drying on the energy of water evaporation of some milk-juice blends and whole milk is shown in Table (5). It could be seen that the total energy of evaporation to produce one $\mathrm{kg}$ of powder increased with increasing both atomization speed and drying temperature for all blends and whole milk. The results showed energy of evaporation ranged from 22.43 to $25.77,23.74$ to 26.52 , and 24.12 to 26.57 GJ to produce one kg of powder from milk-banana, milkstrawberry, and milk-pear blends, respectively, whereas, it ranged from 22.19 to 26.79 GJ for whole milk. 
Table (5) Effect of atomization speed and temperature of spray drying on the energy of evaporation and specific energy consumption.

\begin{tabular}{|c|c|c|c|c|c|c|c|c|}
\hline \multirow{2}{*}{ Treatments } & \multirow{2}{*}{\multicolumn{2}{|c|}{$\begin{array}{l}\text { Tempera } \\
\text { ture }\left({ }^{\circ} \mathrm{C}\right)\end{array}$}} & \multicolumn{2}{|c|}{190} & \multicolumn{2}{|c|}{220} & \multicolumn{2}{|c|}{250} \\
\hline & & & $\mathrm{E}_{\mathrm{ev}}$ & SEC, & $\mathrm{E}_{\mathrm{ev}}$ & SEC, & $\mathrm{E}_{\mathrm{ev}}$ & SEC, \\
\hline \multirow{3}{*}{$\begin{array}{l}\text { Milk- } \\
\text { Banana }\end{array}$} & \multirow{6}{*}{ 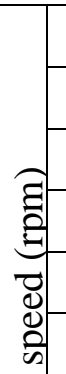 } & 18000 & 22.43 & 53.29 & 22.73 & 51.95 & 23.86 & 49.50 \\
\hline & & 22000 & 22.83 & 49.32 & 23.50 & 48.78 & 24.04 & 47.31 \\
\hline & & 26000 & 23.27 & 44.97 & 24.17 & 43.56 & 25.77 & 42.41 \\
\hline \multirow{3}{*}{$\begin{array}{l}\text { Milk - } \\
\text { Strawberry }\end{array}$} & & 18000 & 23.74 & 51.87 & 23.43 & 48.60 & 26.21 & 42.41 \\
\hline & & 22000 & 24.52 & 48.67 & 23.46 & 46.08 & 25.89 & 41.20 \\
\hline & & 26000 & 24.65 & 44.93 & 26.24 & 44.57 & 26.52 & 37.33 \\
\hline \multirow{3}{*}{ Milk -Pear } & . & 18000 & 24.12 & 50.46 & 23.6 & 49.68 & 26.17 & 47.53 \\
\hline & . ָּ: & 22000 & 24.94 & 45.50 & 26.16 & 44.29 & 26.47 & 42.94 \\
\hline & हี & 26000 & 24.91 & 38.99 & 26.16 & 38.43 & 26.57 & 36.47 \\
\hline \multirow{3}{*}{$\begin{array}{l}\text { Whole } \\
\text { milk }\end{array}$} & $\pi$ & 18000 & 22.19 & 45.70 & 23.05 & 44.93 & 26.52 & 43.12 \\
\hline & & 22000 & 22.42 & 41.41 & 23.09 & 39.96 & 26.66 & 38.79 \\
\hline & & 26000 & 22.66 & 39.96 & 22.48 & 39.24 & & 38.53 \\
\hline
\end{tabular}

Concerning, the total energy consumed which decreased with increasing both atomization speed and drying temperature for all blends and whole milk, it ranged from 36.47 to $53.29 \mathrm{GJ} / \mathrm{kg}$ for milk-juices blends, whereas, it ranged from 38.53 to $45.70 \mathrm{GJ} / \mathrm{kg}$ for whole milk. The results revealed that the specific energy consumption of the laboratory scale driers was much higher than that of the commercial driers as mentioned by Baker and McKenzie. (2002), which is attributed to huge losses of energy during the operation of these small driers without air recirculation.

\section{Thermal efficiency:}

The effect of atomization speed (18000, 22000, and $26000 \mathrm{rpm})$ and temperature $\left(190,220\right.$ and $\left.250^{\circ} \mathrm{C}\right)$ of spray drying on the thermal efficiency of drying of some milk-juice blends and whole milk is shown in Table (6). It could be seen that the thermal efficiency increased with increasing both atomization speed and drying temperature for all blends 
and whole milk. The lowest efficiency (42.09\%) was recorded at $190{ }^{\circ} \mathrm{C}$ drying temperature and $18000 \mathrm{rpm}$ atomization speed, while the highest efficiency $(71.03 \%)$ was recorded at $250{ }^{\circ} \mathrm{C}$ drying temperature and $26000 \mathrm{rpm}$ atomization speed. The thermal efficiency ranged from 48.55 to $69.54 \%$ for drying the whole milk. These results agreed with those obtained by Bimbent et al. (2002).

Table (6) effect of atomization speed and temperature of spray drying on the drying efficiency of some dried milk-juice blends

\begin{tabular}{|c|c|c|c|c|c|}
\hline \multirow[b]{2}{*}{ Treatments } & \multicolumn{2}{|c|}{ Temperature } & 190 & 220 & 250 \\
\hline & & & \multicolumn{3}{|c|}{ Thermal Efficiency (\%) } \\
\hline \multirow{3}{*}{ Milk- Banana } & \multirow{5}{*}{ 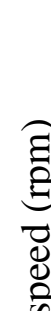 } & 18000 & 42.09 & 43.75 & 48.21 \\
\hline & & 22000 & 46.29 & 48.18 & 50.81 \\
\hline & & 26000 & 51.75 & 55.48 & 58.73 \\
\hline \multirow{3}{*}{$\begin{array}{l}\text { Milk - } \\
\text { Strawberry }\end{array}$} & & 18000 & 45.77 & 48.21 & 61.80 \\
\hline & & 22000 & 50.37 & 50.92 & 62.84 \\
\hline & के & 26000 & 54.87 & 58.87 & 71.03 \\
\hline \multirow{3}{*}{ Milk -Pear } &.$气$ & 18000 & 47.80 & 47.53 & 55.07 \\
\hline & స్ & 22000 & 54.80 & 59.07 & 61.66 \\
\hline & $\approx$ & 26000 & 63.88 & 68.08 & 72.85 \\
\hline \multirow{3}{*}{ Whole milk } & $\bar{z}$ & 18000 & 48.55 & 51.30 & 61.51 \\
\hline & & 22000 & 54.13 & 57.79 & 68.72 \\
\hline & & 26000 & 56.69 & 57.28 & 69.54 \\
\hline
\end{tabular}

\section{Theoretical approach results and discussions:}

\section{The inputs and outputs of energy results:}

Theoretical approach results of inputs and outputs energy ( $\mathrm{kJ} / \mathrm{kg}$ powder) for the spray dryer used to dry milk-banana blends at 18000, 22000, and $26000 \mathrm{rpm}$ as shown in Table (7).

There is a difference of $2079.93 \mathrm{~kJ} / \mathrm{kg}$ between the energy input and output, which represents $4.28 .6 \%$, this could be losses from the dryer walls, cyclone, atomizer connection, air exhaust pipe surface and with solids lost with the leaving air. The same trend was occurred at the both 220 and $250{ }^{\circ} \mathrm{C}$ drying temperatures and different atomization speeds 
Table (7): Energy (E) inputs and outputs at different atomization speeds for drying milk-banana blends at different temperatures.

\begin{tabular}{|c|c|c|c|}
\hline \multirow{3}{*}{ At $18000 \mathrm{rpm}$} & \multicolumn{3}{|c|}{ Drying temperature, ${ }^{\circ} \mathrm{C}$} \\
\hline & 190 & 220 & 250 \\
\hline & \multicolumn{3}{|c|}{ Inputs } \\
\hline E air, $\mathrm{kJ} / \mathrm{kg}$ & 46463.54 & 44278.64 & 41625.24 \\
\hline $\mathrm{E}$ liquid, $\mathrm{kJ} / \mathrm{kg}$ & 2015.13 & 2021.16 & 2115.67 \\
\hline E solid, $\mathrm{kJ} / \mathrm{kg}$ & 107.54 & 107.86 & 112.91 \\
\hline \multirow[t]{2}{*}{ Total } & 48586.21 & 46407.66 & 43853.82 \\
\hline & \multicolumn{3}{|c|}{ Outputs } \\
\hline $\mathrm{E}$ air, $\mathrm{kJ} / \mathrm{kg}$ & 46324.29 & 44221.68 & 41656.34 \\
\hline E solid, $\mathrm{kJ} / \mathrm{kg}$ & 181.98 & 183.06 & 191.62 \\
\hline Total & 46506.27 & 44404.73 & 41847.96 \\
\hline Difference, $\%$ & 4.28 & 4.32 & 4.57 \\
\hline At $22000 \mathrm{rpm}$ & \multicolumn{3}{|c|}{$\begin{array}{l}\text { Drying temperature, }{ }^{\circ} \mathrm{C} \\
\text { Inputs }\end{array}$} \\
\hline $\mathrm{E}$ air, $\mathrm{kJ} / \mathrm{kg}$ & 42520.14 & 42319.41 & 39643.08 \\
\hline E liquid, $\mathrm{kJ} / \mathrm{kg}$ & 2033.495 & 1970.792 & 2134.301 \\
\hline $\mathrm{E}$ solid, $\mathrm{kJ} / \mathrm{kg}$ & 108.5198 & 105.1736 & 113.8995 \\
\hline \multirow[t]{2}{*}{ Total } & 44662.15 & 44395.38 & 41891.29 \\
\hline & \multicolumn{3}{|c|}{ Outputs } \\
\hline $\mathrm{E}$ air, $\mathrm{kJ} / \mathrm{kg}$ & 42392.71 & 42264.96 & 39672.71 \\
\hline E solid, $\mathrm{kJ} / \mathrm{kg}$ & 182.7202 & 172.7579 & 186.0852 \\
\hline Total & 42575.43 & 42437.72 & 39858.79 \\
\hline Difference, $\%$ & 4.67 & 4.40 & 4.85 \\
\hline
\end{tabular}

\begin{tabular}{lccc} 
At $26000 \mathrm{rpm}$ & \multicolumn{3}{c}{ Drying temperature, ${ }^{\circ} \mathrm{C}$} \\
& \multicolumn{3}{c}{ Inputs } \\
\hline E air, $\mathrm{kJ} / \mathrm{kg}$ & 38576.74 & 35462.1 & 34137.1 \\
E liquid, $\mathrm{kJ} / \mathrm{kg}$ & 2075.52 & 2138.884 & 2127.569 \\
E solid, kJ/kg & 110.76 & 114.144 & 113.5402 \\
\multicolumn{1}{c}{ Total } & $\mathbf{4 0 7 6 3 . 0 2}$ & $\mathbf{3 7 7 1 5 . 1 3}$ & $\mathbf{3 6 3 7 8 . 2 1}$ \\
\hline \multicolumn{4}{c}{ Outputs } \\
\hline E air, $\mathrm{kJ} / \mathrm{kg}$ & 38461.13 & 35416.48 & 34162.61 \\
E solid, $\mathrm{kJ} / \mathrm{kg}$ & 186.4961 & 187.4927 & 185.4982 \\
\hline \multicolumn{1}{c}{ Total } & $\mathbf{3 8 6 4 7 . 6 2}$ & $\mathbf{3 5 6 0 3 . 9 7}$ & $\mathbf{3 4 3 4 8 . 1 1}$ \\
\hline Difference, \% & 5.19 & 5.58 & 5.59 \\
\hline \hline
\end{tabular}




\section{Comparison between actual and estimated energy consumption of the spray dryer:}

Table 8 shows the actual and estimated energy consumption of the spray dryer at different temperatures and atomization speeds for drying bananamilk blends. It indicates that there is a difference between them and always the actual energy consumption was higher than the estimated ones, this may be attributed to that some energy losses from the exhaust pipe of the dryer and with the powder lost out with exhaust air were neglected during the estimation.

Table (8): the actual and estimated energy consumption of the spray dryer at different temperatures and atomization speeds for drying bananamilk blends.

\begin{tabular}{cccc}
\hline \hline $\begin{array}{c}\text { Atomization } \\
\text { speed, rpm }\end{array}$ & $\begin{array}{c}\text { Temperature, } \\
\mathrm{C}\end{array}$ & $\begin{array}{c}\text { Actual energy, } \\
\mathrm{kJ} / \mathrm{kg}\end{array}$ & $\begin{array}{c}\text { Estimated } \\
\text { energy, } \mathrm{kJ} / \mathrm{kg}\end{array}$ \\
\hline \hline \multirow{3}{*}{18000} & 190 & 53288.80 & 48586.21 \\
& 220 & 51945.20 & 46407.66 \\
22000 & 250 & 49501.70 & 43853.82 \\
& 190 & 49317.30 & 44662.15 \\
& 220 & 48780.00 & 44395.38 \\
26000 & 250 & 47314.20 & 41891.29 \\
& 190 & 44966.20 & 40763.02 \\
\hline \hline
\end{tabular}

\section{CONCLUSION}

A laboratory scale-spray dryer performance was evaluated and investigated experimentally under different drying temperatures and atomization speeds. Energy consumption for drying was investigated experimentally and theoretically.

The results indicated that the drying temperature and atomization speed have profound effect on the spray dryer performance, powder yield, drying time and the final moisture content of the powder decreased with increasing both temperature and atomization speed, meanwhile, drying 
rate, feeding rate, thermal efficiency increased with increasing the drying temperature and atomization speed. It is worthy to mention that the effect of drying temperature on the dryer performance was higher than that of the atomization speed. Real water evaporation rate increased with increasing both drying temperature and atomization speed. Energy consumption decreased with increasing both drying temperature and atomization speed. Energy inputs and outputs calculations showed that there is a difference between the energy calculated inputs and outputs ranged from 4.28 to $5.59 \%$, which is attributed to some loses were not taken into consideration during calculations such as losses from the exhaust pipe and fine powder gone with exhaust air. Also, the theoretical approach showed that it could be recycling the exhausted air to save energy.

Further work should be done to increase the thermal efficiency of the dryer. Also, future studies are required to optimize the operational conditions of such dryers and investigating the possibility of saving energy.

\section{REFERENCES}

Baker, C. G. J and K.A. McKenzie. 2002. Energy consumption of industrial spray dryers. Drying' 2002-Proceedings of the 13th International Drying Symposium (IDS' 2002) Beijing, China, 27-30 August' 2002, vol. A, pp. 645.

Bimbenet, J., Schuck, P., Roignant, M., Brul, G., and S. Mejan. 2002. Heat balance of a multistage spray-dryer: principles and example of application. Lait 82 (2002): 541-551

Birchal, V.S., Huang, L., Mujumdar, A.S., and Passos, M.L., 2006. Spray dryers: modeling and simulation. Drying Technology 24 (3), 359371.

Deis, R.C. 1997. Spray-drying - innovative use of an old process. FoodProduct-Design. 1997, 7(2): 97-98, 100, 103-104, 107, 109, 111113.

Goula, A. M. and K. G. Adamopoulos .2003. Spray Drying Performance of a Laboratory Spray Dryer for Tomato Powder Preparation Drying Technology, 21 (7): 1273 - 1289. 
Hanus, M.J., and Langrish, T.A.G., 2007. Re-entrainment of wall deposits from a laboratory-scale spray dryer. Asia-Paci. Journal of Chemical Engineering 2 (2), 90-107.

Huang, L., Kumar, K., and Mujumdar, A.S., 2003a. A parametric study of the gas flow patterns and drying performance of co-current spray dryer: results of a computational fluid dynamics study. Drying Technology 21 (7), 957-978.

Huang, L., Kumar, K., and Mujumdar, A.S., 2003b. Use of computational fluid dynamics to evaluate alternative spray chamber configurations. Drying Technology 21 (3), 385-412.

Huang, L.X., Kumar, K., and Mujumdar, A.S., 2004. Simulation of a spray dryer fitted with a rotary disk atomizer using a three dimensional computational fluid dynamic model. Drying Technology 22 (6), 1489-1515.

Kessler H.G., 1981. Food engineering and dairy technology, Verlag A. Kessler, Freising, Germany, 1981.

Kota, K. and Langrish, T.A.G., 2007a. Assessing the deposition of a water spray on a plate in a simple box configuration using computational fluid dynamics (CFD). Chemical Product and Process Modelling 2 (3), 1-15. Available from: http://www.bepress.com/ijfe/vol2/iss3/16.

Kota, K and Langrish, T.A.G., 2007b. Prediction of deposition patterns in a pilot-scale spray dryer using computational uid dynamics (CFD) simulations. Chemical Product and Process Modelling 2 (3), 26-41. Available from: http:// www.bepress.com/ijfe/vol2/iss3/26

Langrish, T. 2009. Multi-scale mathematical modelling of spray dryers. Journal of Food Engineering , 93:218-228

Ozmen L. and T. A. G. Langrish. .2003a. A Study of the Limitations to Spray Dryer Outlet Performance. Drying technology, vol. 21, No. 5, pp. 895-917.

Ramaswamy, H. and M. Marcotte, 2006. Food processing, principles and applications, Taylor \& Francis Group, LLC, pages, 300-301. 
Rane, M. V. ,S.V. Kota Reddy, and R. R. Easow. (2005) Energy efficient liquid desiccant-based dryer. Applied Thermal Engineering 25 (2005) 769-781.

Rao, RH and Kumar, A.H. 2005. Spray drying of mango juice-Buttermilk blends. Lait, 85, (4-5): 395-404.

Truong, V., Bhandari, B.R., and Howes, T., 2005. Optimization of cocurrent spray drying process of sugar-rich foods. Part I - Moisture and glass transition temperature profile during drying. Journal of Food Engineering 71 (1), 55-65.

\section{الملخص العربي \\ تقييم آداء مجفف رذاذ معملى

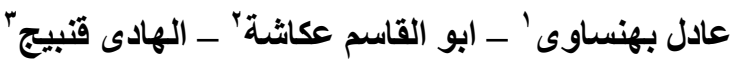

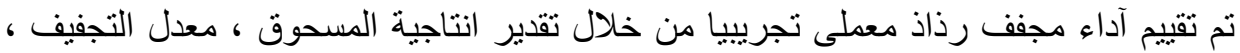

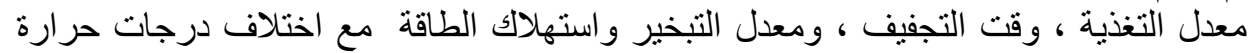

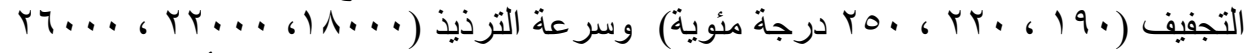

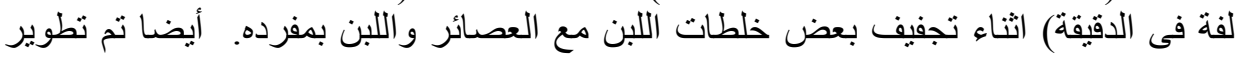

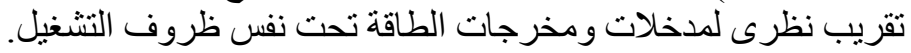

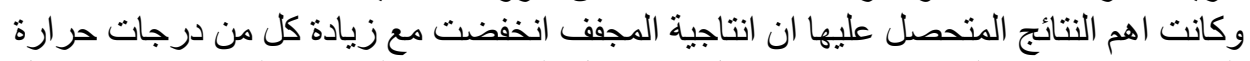

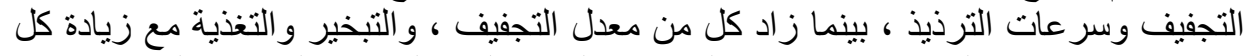

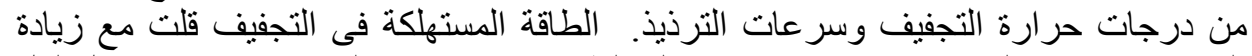

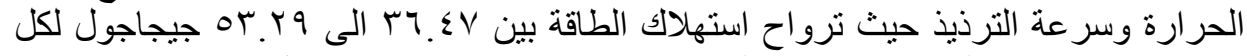

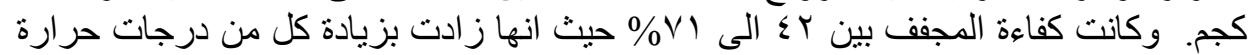
التجفيف وسر عات الترذيذ ايضا. التقريب النظرى اظهر ان الطاقة المحسوبة اقل من الفعلية وذلك بسبب الطاقة المفقودة من جدار

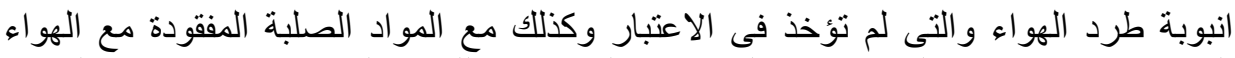

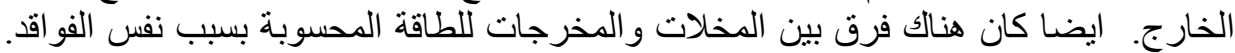

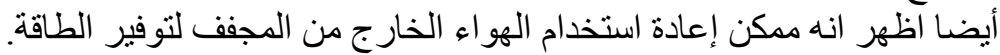
هذا البحث يقدم معلومات وبيانات هامة تساعد الباحثين و العاملين فى مجال التجفيف بصفة التهة عامة التهات

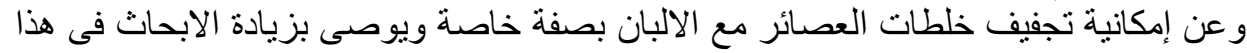

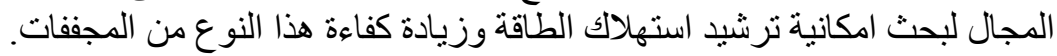

الكلمات الألة: مجفف الرذاذ - حرارة التجفيف - سرعة الترذيذ - استهلاك الطاقة - اداء المجفف - مسحوق التجفيف.

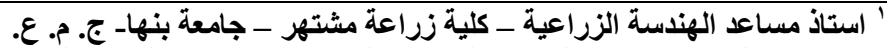

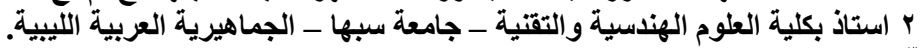

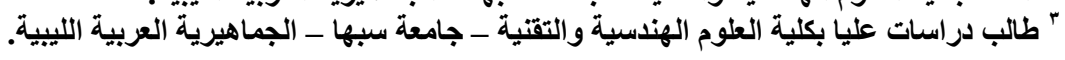

